\title{
Sensitivity Of Socially Responsible Investment Behaviour To Experience And Size Of Funds
}

\author{
Mohammad Talha, Prince Mohammad Bin Fahd University, Saudi Arabia \\ Abdullah Sallehhuddin Abdullah Salim, Universiti Teknologi MARA / Multimedia University, Malaysia \\ Abdul Aziz Abdul Jalil, Universiti Teknologi MARA / Multimedia University, Malaysia \\ Norzarina Md Yatim, Multimedia University, Malaysia
}

\begin{abstract}
This paper examines the moderating effect of experience and size of fund towards socially responsible investment (SRI).A survey was conducted to get the responses of fund managers, and data were analysed using a multi-group approach of Structural Equation Modelling (SEM).At intentional level, there was a significant moderating effect on the relationship between attitudes and caring ethical climate towards an intention to SRI among less experienced fund managers. There was a significant moderating effect on the relationship between subjective norms and perceived behavioural control towards an intention to SRI among more experienced fund managers. There was also a significant moderating effect on the relationship between subjective norms and caring ethical climate towards an intention to SRI among small-sized fund managers. At behavioural level, there was a significant moderating effect on the relationship between moral intensity and SRI behaviour among less experienced fund managers. There was also a significant moderating effect on the relationship between moral intensity and caring ethical climate on SRI behaviour among bigger-sized fund managers. This paper conduits the literature gap by expanding the understanding on the moderating impact of experience and size of fund towards SRI, provides insights to policy makers in carrying out appropriate talent development strategies in accumulating the support of fund managers towards SRI-related initiatives in the capital market, and reveals the potential contribution of fund manager talent management in sustainable development through SRI. The paper offers vision on fund manager talent management to forefront the progress of SRI in emerging economies.
\end{abstract}

Keywords: Socially Responsible Investment; Experience; Size Of Fund; Fund Managers

\section{INTRODUCTION}

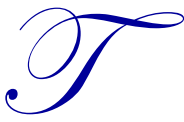

he assessment of demographic attributes in the area of investment first appeared in the 1970s. Cohn, Lewellen, Lease, and Schlarbaum (1975) found that risk-aversion was inversely related to investor wealth. Subsequently, Lewellen, Lease, and Schlarbaum, (1977) evidenced that "age, gender, income, and education influenced investor preferences for capital gains, dividend yield, and overall return." More than a decade later, Warren, Stevens, and McConkey (1990) concluded that lifestyle and demographic factors influenced investor choice among asset classes. Riley and Chow (1992) showed that risk-aversion behaviour decreased as age, income and level of education and wealth increased.

Owen and Qian (2008) observed that in a socially responsible investment (SRI) context, less-educated investors were more likely to consider ethical, social, and governance (ESG)while taking investment decisions. Nilsson (2008)showed that better-educated investors had a higher tendency to invest in SRI funds. Owen and Qian (2008), and Nilsson (2008)had one finding in common - women investors were more likely to involve in SRI funds. Rosen, Sandler and Qian (1991) found that SRI investors were younger and were more educated. Tippet and Leung (2001) showed that SRI investors were more likely to be female, younger, and better educated. Martin and Nisar (2007) attempted to establish evidence on the influence of investors' working experience, age, and size of a fund managed on their behaviour; however, the results were diverse. 
In short, demographic attributes have been examined in multiple attempts of SRI research. Most of the studies focused on the direct effect of demographic characteristics on the SRI behaviour (see Rosen et al. 1991; Beal \& Goyen, 1998;Eckel Grossman, 1998; Owen \& Qian, 2008; Nilsson, 2008; 2009). Several studies compared demographic attributes between socially responsible and non-socially responsible investors (see, Lewis, 2001; Tippet \& Leung, 2001; MacLachlan \& Gardner, 2004).

Despite detailed investigations, on the intervening effects i.e. moderating effects of demographic attributes on the linkage between interconnected variables in SRI behaviour model are limited. However, the importance of potential intervening impactof demographic attributes towards understanding intention/motivation and behaviour in business settings has been duly felt by Ford and Richardson (1994), Loe, Ferrell, and Mansfield (2000), O'Fallon and Butterfield (2005),Craft (2012), and Lehnert, Park and Singh (2014). The impact of appreciating dynamic moderating effects on the antecedents of intention and behaviour in a commercial environment like SRI engagement helps relevant policy makers, fund managers, institutional investors, regulators, and business associations formulate suitable strategies for the benefits of the industry as a whole. This study aims to provide details on the interactive effect of moderating variables in the integrated and validated SRI behaviour model. Hence, it is the purpose of this study to fill up the existing gap.

\section{HYPOTHESIS FORMULATION}

\section{Experience}

Experience is likely to have a pronounced effect upon SRI behaviour. Investors who have worked for a longer period are expected to perform certain behaviour since they are more aware of the organisational demands and ethical, social, governance (ESG) expectations than investors with lesser experience. In a related study, Tan and Komaran (2006) evidenced that professionals in Singapore with longer working experience rated ethical responsibility higher than economic responsibility.

Martin and Nisar (2007)found that experienced institutional investors were more involved in monitoring ESG performance of investee companies than less-experienced institutional investors. They argued that longer experience indicated institutional investors' high level of maturity, acquisition of relevant skills, good understanding of the investee companies and market conditions of their business for performing SRI behaviour.

In the context of institutional investors' investment behaviour, Mishra and Metilda (2015) found that experienced mutual fund managers were more overconfident than less experienced counterparts in Indian financial market. Besides, Islamoglu, Apan and Ayvali (2015) also found that experience was a significant predictor to investment behaviour among bankers in Turkish market. These findings corroborated with earlier study by Menkhoff, Schmeling and Schmidt (2013) where investment experience significantly impacted the level of overconfidence among institutional investors. Additionally, Lodhi (2014) and Geeta and Vimala (2014) also found significant influence of experience on investment behaviour and decision-making process. In addition, Sadig and Ishaq (2014) established impact of investment experience towards investors' risk tolerance behaviour.

Given the preceding discussion, this study aims to assess the contribution of the level of experience in influencing SRI behaviour among institutional investors. Thus, the following hypothesis has been framed;

$\mathbf{H}_{1}$ : There is a moderation effect of experience towards socially responsible investment behaviour.

\section{Size of Fund Managed}

Regarding the size of fund managed, Martin and Nisar (2007) found that the variable was not a significant predictor of SRI behaviour. Similarly, Gregory, Matatko and Luther (1997) found less influence of the size of fund towards SRI. In contrast, Chiu and Monin (2003) and Sievanen, Rita and Scholtens (2013) argued that institutional investors with bigger size of fund to manage were likely to be more active in monitoring governance practices among investee companies than investors with a smaller size of the fund because a larger size of a fund managed represented higher degree of responsibility.Solomon and Solomon (2003) argued that as the size of fund managed grew, concern 
towards SRI also improved to avoid reputational risks due to non-compliance of investee companies against established ESG standards. Furthermore, Useem, Bowman, Myattand Irvine (1993)contended that depending on the size of fund managed, SRI behaviour varied.Investors with large fund to manage tended to engage actively through voting as a unified bloc, while small investors decided to hold their investment and hoped for incerease in the value of their shares.

In several related studies, level of investors' income effect towards investment behaviour were assesed. A study by Islamoglu et al. (2015) discovered that level of income was a significant predictor to investment behaviour among bankers in Turkish market. Similarly, Sadig and Ishaq (2014) found a significant influence of level of income towards risk tolerance behaviour among Pakistani investors. Several studies also have examined the income level perspective, while profiling for socially responsible investors. Studies by Perez-Gladish, Benson and Faff (2012), Junkus and Berry (2010), Woodward (2000), and Rosen et al. (1991) indicated that socially responsible investors largely belonged to low-income group. Nevertheless, McLachlan and Gardner (2004) and Getzner and GrabnerKrautner (2004) found that socially responsible investors largelycame from high-income group.

This study, therefore, aims to assess the effect of size of fund managed on SRI behaviour. Therefore, the following hypothesis has been formulated:

$\mathbf{H}_{2}$ : There is a moderation effect of size of fund managed towards socially responsible investment behaviour.

\section{METHODS}

\section{Research Framework and Variables of Study}

The core framework of this study is 'Theory of Planned Behaviour' (TPB) by Ajzen (1985). TPB stated that attitudes, subjective norms, and perceived behavioural control predict intention. Subsequently, intention predicts behaviour. The framework is extended with the inclusion of two more indicators namely moral intensity, which was introduced by Jones (1991) in the Issue-Contingent Model and caring ethical climate - a component of Ethical Climate Theory by Victor and Cullen $(1987 ; 1988)$. According to Jones (1991), the moral intensity is expected to influence intention and behaviour. He contends further that organisational factor also predicts intention and behaviour. Hence, in this study, the caring ethical climate is used as a proxy to organisational factor. Therefore, the study expects that caring ethical climate will influence intention and behaviour. Figure 1 illustrates the relationship among predictors in the research framework.

Experience and size of fund managed are engaged as moderating variables. A moderator variable is a 'variable that alters the strength of the causal relationship between independent and dependent variable' (Baron \& Kenny, 1986, p. 1174). It is expected that experience and size of fund managed will moderate the relationship between attitudes, subjective norms, perceived behavioural control, moral intensity, and caring ethical climate towards intention to engage in SRI. Experience and size of fund managed are expected to moderate the relationship between intention, moral intensity, and caring ethical climate towards SRI behaviour.

From Figure 1, attitude, subjective norms, perceived behavioural control, moral intensity, and caring ethical climate are expected to determine intention towards SRI. Besides, intention, perceived behavioural control, moral intensity, and caring ethical climate are also expected to determine SRI behaviour. Hence, intention mediates the relationship between perceived behavioural control, moral intensity, and caring ethical climate towards SRI behaviour. Furthermore, experience and size of fund managed are expected to moderate the relationship towards intention to SRI and SRI behaviour respectively. 
Figure 1. Research Framework

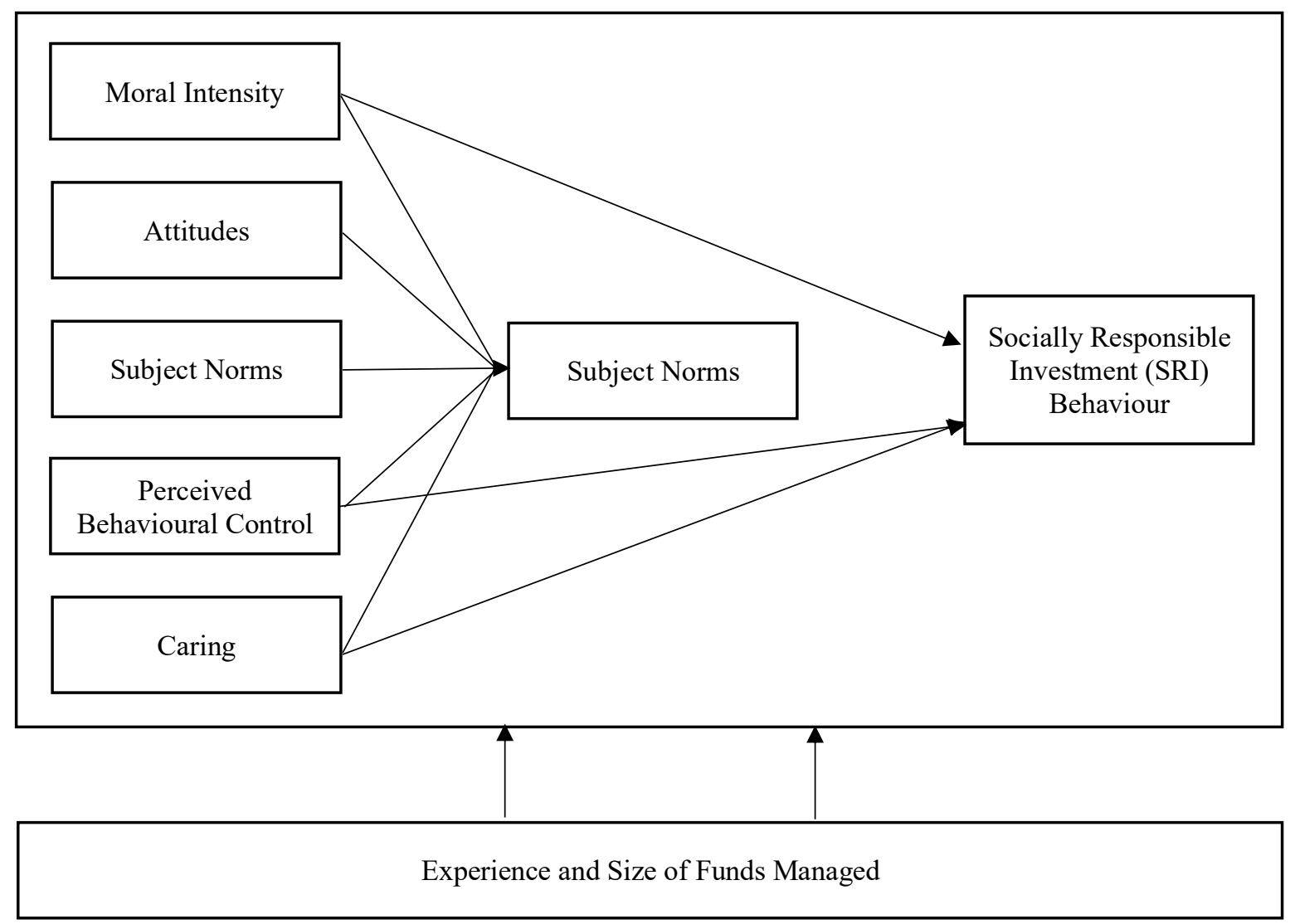

\section{Research Population and Sampling}

The population of this study consists of Malaysian institutional investors. These investors are likely to participate in SRI as explained in the past studies of Cox, Brammer and Millington (2004), Sethi (2005), Hellsten and Mallin (2006), and Nilsson (2009). Table 1 shows the types such investors. There are 229 Malaysian institutional investors who are included in the present study.

Table 1. Malaysian Institutional Investors Itemization

\begin{tabular}{l|c}
\hline \multicolumn{1}{c}{ Types of Institutional Investors } & Number \\
\hline Stock Broking Company (Non-investment Banks) & 20 \\
\hline Stock Broking Company (Investment Banks) & 14 \\
\hline Insurance Companies & 47 \\
\hline TakafulProviders & 13 \\
\hline Fund Management Companies & 87 \\
\hline Public Institutional Investors (Federal Level) & 11 \\
\hline Public Institutional Investors (State Level) & 37 \\
\hline Total & 229 \\
\hline
\end{tabular}

Adopting Ku Ismail and Chandler (2005), a package containing five questionnaires and a covering letter was mailed to the head of fund managers at every 229 institutional investor entities. Thus, 1,145 survey forms were posted. The letter elaborated the purposes of the investigation and detailed the assistance needed. In order toencourage greater response, self-addressed and self-stamped reply envelopes were also sent along with the questionnaires. 
From 1,145 questionnaires delivered, a total of 402 were received, indicating 35percent response rate. A common response rate in the Malaysian context, when questionnaires are used is16percent (PricewaterhouseCoopers, 2002; $\mathrm{Ku}$ Ismail \& Chandler (2005). As part of data screening procedures, these 402 questionnaires were scrutinised for potential missing value, outliers, and normality. Ultimately, 308 questionnaires were found fit for next stage analysis, demonstrating a usable rate of 26.9 per cent.

\section{RESEARCH ANALYSIS TECHNIQUE}

Moderating effect in Structural Equation Modelling (SEM) was examined through multi-group analysis (Abu Samah, 2014). A multi-group analysis groups the respondents into two categorical variables viz. Group 1 and Group 2. In this study, experience was coded into two groups namely, more experienced and less experienced. The more experienced group refers to respondents who have working experience as a fund manager for ten years and more. The less experienced group refers to respondents who have working experience as a fund manager less than ten years. Size of fund managed was coded into bigger size of fund managed, and smaller size of fund managed. Bigger size fund refers to fund of RM 1 billion and more. Smaller size fund refers to fund less than RM 1 billion. The coding procedures were carried out via median split technique in SPSS 18 software, before embarking multi-group analysis through AMOS software.

A multi-group analysis involves two stages. The first stage requires moderation effect examination on the overall model. The moderation effect is establishedby comparing the Chi-square, $X^{2}(\mathrm{CMIN})$ of variant-group against invariant-group. If the $X^{2}$ of variantgroup is smaller than invariant group, it shows the presence of moderation effect in the model. Additionally, if the difference value of $X^{2}$ and degree of freedom $(d f)$ between variant-group against invariant-group is significant, it verifies the presence of moderation effect on the overall model.

The second stage assesses moderation effect at each path in the model under study. Hair, Black, Babin and Anderson (2010) explained that a particular individual path is moderated if beta for Group 1 is significant, while beta for Group 2is insignificant. Furthermore, if both groups are significant; one group has a positive beta, while the other group has a negative beta (Hair et al. 2010).

\section{RESULTS AND DISCUSSION}

The descriptive analysis has revealed that 98respondents are more experienced representing 31.81 percent of the sample size. The remaining 210 are labelled less experienced representing for 68.18percent of the sample size. Furthermore, 127 respondents are categorised as bigger size fund managers representing 41.23percent of the sample size. One hundred and eighty-one are small size fund managers accounting for 58.76percent of the sample size.

\section{Working Experience}

At the first stage of multi-group analysis, the variantgroup and the invariant-group were compared regarding the $X^{2}$, $d f$, and $p$-value. The results depicted that unconstrained group $\left(X^{2}=512.88, d f=342 ; p<0.05\right)$ was better than measurement residual group $\left(X^{2}=662.17 ; d f=402 ; p<0.05\right)$; as $X^{2}$ of unconstrained model was smaller than $X^{2}$ of the measurement residual group. Besides, the analysis showed that the $X^{2}$ difference was $149.29(662.17-512.88)$, and the $d f$ was $60(402-342)$ and $p<0.05$. Thus, it demonstrated that there was a moderation effect of experience on the SRI behaviour model. Hence, Hypothesis 1 is supported. These findings support earlier assessment by Martin and Nisar (2007) on the influence of experience towards SRI behaviour among institutional investors in the United Kingdom. In a similar vein, Tan and Komaran (2006) also discovered the influence of experience among professionals in Singapore towards the social responsibility conduct.

The second stage examined the moderation effect of experience on each path in the model under study. Table 2 depicts the output of the second stage of multi-group analysis fort the moderating effect of experience on the relationship between predictors and intention to engage in SRI. Table 3 shows the moderation test of experience on each path between predictors and SRI behaviour. 
The results of Table 2 show that experience moderates the individual path between attitude and intention (less than 10 years: $\beta=0.26 ; p=0.02 ; 10$ years and more: $\beta=0.05 ; p=0.74$ ), between subjective norms and intention (less than 10 years: $\beta=0.11 ; p=0.11 ; 10$ years and more: $\beta=0.26 ; p=0.03)$, between perceived behavioural control and intention (less than 10 years: $\beta=0.17 ; p=0.14 ; 10$ years and more: $\beta=0.61 ; p=0.00$ ), and also between caring ethical climate and intention (less than 10 years: $\beta=0.41 ; p=0.00 ; 10$ years and more: $\beta=-0.10 ; p=0.62$ ).

It is evidenced that experience moderates the relationship between attitude and caring ethical climate towards an intention to engage in SRI among less experienced respondents. Besides, the moderating influence has strengthened the prediction, as beta coefficient has improved from 0.26 to 0.41 respectively. It is found that experience moderates the relationship between subjective norms, and perceived behavioural control towards an intention to engage in SRI among more experienced respondents. Additionally, the moderating influence has strengthened the prediction, as beta coefficient improved from 0.26 to 0.61 respectively. Hence, it indicates that more experienced institutional investors are influenced by personal factors only i.e. subjective norms and perceived behavioural control while less experienced institutional investors are affected by both personal factors, i.e. attitude and organisational factor i.e. caring ethical climate. The analysis also shows that experience is a non-moderator in the relationship between moral intensity and intention to engage in SRI behaviour.

Table 2. Results of Moderation Test of Experience on Relationship between Predictors and Intention to Engage in SRI

\begin{tabular}{|c|c|c|}
\hline $\begin{array}{c}\text { Construct and Group } \\
\text { (Less experienced, } n=210 \text { ) } \\
\text { (More experienced, } n=98 \text { ) }\end{array}$ & Beta & $p$ \\
\hline \multicolumn{3}{|l|}{ Attitude } \\
\hline Less Experienced & 0.26 & 0.02 \\
\hline More Experienced & 0.05 & 0.74 \\
\hline \multicolumn{3}{|l|}{ Subjective Norms } \\
\hline Less Experienced & 0.11 & 0.11 \\
\hline More Experienced & 0.26 & 0.03 \\
\hline \multicolumn{3}{|l|}{ Perceived Behavioural Control } \\
\hline Less Experienced & 0.17 & 0.14 \\
\hline More Experienced & 0.61 & 0.00 \\
\hline \multicolumn{3}{|l|}{ Moral Intensity } \\
\hline Less Experienced & 0.03 & 0.72 \\
\hline More Experienced & 0.15 & 0.25 \\
\hline \multicolumn{3}{|l|}{ Caring Ethical Climate } \\
\hline Less Experienced & 0.41 & $* * *$ \\
\hline More Experienced & -0.10 & 0.62 \\
\hline
\end{tabular}

The outcomes of Table 3 showed that experience moderated the individual path between moral intensity and SRI behaviour (less than 10 years: $\beta=0.20 ; p=0.02 ; 10$ years and more: $\beta=0.11 ; p=0.40$ ). It indicates that experience moderates the relationship between moral intensity and SRI behaviour; hence, the moderating influence has strengthened the prediction as beta coefficient that has improved to 0.20 among less experienced institutional investors group. It projects that SRI behaviour among less experience group of institutional investors is largely influenced by contextual factor i.e. moral intensity. The analysis also shows that experience is a non-moderator in the relationship between caring ethical climate and intention towards SRI behaviour. 
Table 3. Results of Moderation Test of Experience on Relationship between Predictors and SRI Behaviour

\begin{tabular}{|c|c|c|}
\hline $\begin{array}{c}\text { Construct and Group } \\
\text { (Less than } 10 \text { years, } n=210 \text { ) } \\
(10 \text { years and more, } n=98)\end{array}$ & Beta & $p$ \\
\hline \multicolumn{3}{|l|}{ Moral Intensity } \\
\hline Less Experienced & 0.20 & 0.02 \\
\hline More Experienced & 0.11 & 0.40 \\
\hline \multicolumn{3}{|l|}{ Caring Ethical Climate } \\
\hline Less Experienced & 0.18 & 0.14 \\
\hline More Experienced & 0.14 & 0.33 \\
\hline \multicolumn{3}{|l|}{ Intention } \\
\hline Less Experienced & 0.12 & 0.36 \\
\hline More Experienced & 0.27 & 0.08 \\
\hline
\end{tabular}

Like age, experience is closely related to a higher maturity of moral reasoning as more experienced individuals have more information, skills, and understanding towards a certain issue. Thus, it is easier for them to make a decision whether to engage or not to engage in certain behaviour. Subjective norms and perceived behavioural control are found to significantly influence intention. With lack of appropriate skills and understanding, less experienced institutional investors have to rely on organisational factor i.e. caring ethical climate, or their evaluation i.e. attitude to influence intention to engage in SRI. A similar pattern is found in Table 3 in which moral intensity of less experienced significantly influence the performance of SRI behaviour. These are exceptional for more experienced institutional investors.

In the context of this study, relevant authorities in emerging market shall take suitable measures to retain more experienced fund managers in a local market to drive SRI behaviour, and eventually lead to exponential growth of local SRI portfolios. An attractive remuneration package is crucial to keep more experienced fund managers and prevent them from leaving for competitors' market such as Middle East, Singapore, Hong Kong, and European market. Moreover, having abundant and more experienced managers are crucial to attract global SRI investors. Without experienced people, it will be difficult to manage complex SRI requirements.

\section{Size of the Fund Managed}

On determining the impact of moderation effects on the overall model under study, the results depict that unconstrained group $\left(X^{2}=513.52, d f=342 ; p<0.05\right)$ is better than the measurement residual group $\left(X^{2}=762.83 ; d f=\right.$ 402; $p<0.05$ ); as $X^{2}$ of unconstrained model is smaller than $X^{2}$ of the measurement residual group. Additionally, the analysis showed that the $X^{2}$ difference is 249.32 (762.83-513.52), the $d f$ is $60(402-342)$ and $p<0.05$. Thus, it is verified that there is a moderation effect of a size of the fund managed on the SRI behavior model. Hence, Hypothesis 2 was supported. These findings are consistent with previous efforts of Chiu and Monin (2003), Solomon and Solomon (2003) and Sievanen et al. (2013) where size of fund managed influenced the SRI behaviour among institutional investors.

After confirming the presence of moderation effects in the overall model under study, the second stage examines moderation effect on each path in the model under study. Table 4 shows the moderation test of size of the fund managed on the individual path between predictors and intention to engage in SRI. Table 5 shows the moderation test of size of fund managed on the individual path between predictors and SRI behaviour. 
Table 4. Results of Moderation Test of Size of Fund Managed on Relationship between Predictors and Intention to Engage in SRI

\begin{tabular}{|c|c|c|}
\hline $\begin{array}{c}\text { Construct and Group } \\
\text { (less than RM1b, } n=181 \text { ) } \\
\text { (RM 1b and more, } n=127 \text { ) }\end{array}$ & Beta & $p$ \\
\hline \multicolumn{3}{|l|}{ Attitude } \\
\hline Less than RM 1 billion & 0.11 & 0.25 \\
\hline RM 1 billion and more & 0.13 & 0.49 \\
\hline \multicolumn{3}{|l|}{ Subjective Norms } \\
\hline Less than RM 1 billion & 0.23 & $* * *$ \\
\hline RM 1 billion and more & -0.12 & 0.48 \\
\hline \multicolumn{3}{|l|}{ Perceived Behavioural Control } \\
\hline Less than RM 1 billion & 0.11 & 0.34 \\
\hline RM 1 billion and more & 0.47 & 0.07 \\
\hline \multicolumn{3}{|l|}{ Moral Intensity } \\
\hline Less than RM 1 billion & 0.02 & 0.75 \\
\hline RM 1 billion and more & 0.03 & 0.87 \\
\hline \multicolumn{3}{|l|}{ Caring Ethical Climate } \\
\hline Less than RM 1 billion & 0.55 & $* * *$ \\
\hline RM 1 billion and more & 0.02 & 0.91 \\
\hline
\end{tabular}

***significant at 0.01 level

Table 4 shows that size of fund managed moderates the individual path between subjective norms and intention (less than RM 1 billion: $\beta=0.23 ; p<0.001$; RM 1 billion and more: $\beta=-0.12 ; p=0.48$ ). It also moderates the individual path between caring ethical climate and intention (less than RM 1 billion: $\beta=0.55 ; p<0.001$; RM 1 billion and more: $\beta=0.02 ; p=0.91$ ). The analysis shows that size of fund managed moderates the relationship between subjective norms and caring ethical climate towards intention to engage in SRI behaviour among respondents who manage small-size fund. Additionally, the beta coefficients improved to 0.23 and 0.55 respectively, showing that moderating influence has strengthened the prediction. The analysis also highlights that size of fund managed is a non-moderator in the relationship between attitude, perceived behavioural control, and moral intensity towards intention to engage in SRI behaviour.

Results of Table 4 showed that size of fund managed moderates the individual path between subjective norms and intention (less than RM 1 billion: $\beta=0.23 ; p<0.001$; RM 1 billion and more: $\beta=-0.12 ; p=0.48$ ). It also moderates the individual path between caring ethical climate and intention (less than RM 1 billion: $\beta=0.55$; $p<$ 0.001; RM 1 billion and more: $\beta=0.02 ; p=0.91$ ). The analysis shows that size of fund managed moderates the relationship between subjective norms and caring ethical climate towards intention to engage in SRI behaviour among respondents who manage a small-sized fund. Additionally, the beta coefficients improved to 0.23 and 0.55 respectively, showing that the moderating influence has strengthened the prediction. The analysis also highlights that size of fund managed is a non-moderator in the relationship between attitude, perceived behavioural control, and moral intensity towards intention to engage in SRI behaviour.

The outcomes of Table 5show that size of fund managed moderates the individual path between caring ethical climate and SRI behaviour (less than RM 1 billion: $\beta=-0.02 ; p=0.90$; RM 1 billion and more: $\beta=0.20 ; p=0.05$ ), and it also moderates the individual path between moral intensity to SRI behaviour (less than RM 1 billion: $\beta=0.00$; $p=0.97$; RM 1 billion and more: $\beta=0.33 ; p=0.01$ ). The analysis shows that size of fund managed moderates the relationship between moral intensity and caring ethical climate towards SRI behaviour among respondents who manage big-sizes fund. Furthermore, the beta coefficientshave increased to 0.25 and 0.20 respectively, confirming that moderating effect has strengthened the prediction. 
Table 5. Results of Moderation Test of a Size of the Fund Managed on Relationship between Predictors and SRI Behaviour

\begin{tabular}{|c|c|c|}
\hline $\begin{array}{c}\text { Construct and Group } \\
\text { (less than RM1b, } n=181 \text { ) } \\
\text { (RM 1b and more, } n=127 \text { ) }\end{array}$ & Beta & $p$ \\
\hline \multicolumn{3}{|l|}{ Moral Intensity } \\
\hline Less than RM 1 billion & 0.00 & 0.97 \\
\hline RM 1 billion and more & 0.25 & 0.01 \\
\hline \multicolumn{3}{|l|}{ Caring Ethical Climate } \\
\hline Less than RM 1 billion & -0.02 & 0.90 \\
\hline RM 1 billion and more & 0.20 & 0.05 \\
\hline \multicolumn{3}{|l|}{ Intention } \\
\hline Less than RM 1 billion & 0.33 & 0.04 \\
\hline RM 1 billion and more & 0.30 & 0.02 \\
\hline
\end{tabular}

Large size of fundmanagedis associated with more responsibility. Normally, such size of funds are supervised by older, more educated, and more experienced institutional investors. Thus, the larger size of fund managed relates with more socially active responsible investment behaviour. These arguments corroborate with the findings in Table 4 and Table 5. For those who manage a small size of fund, subjective norms and caring ethical climate are significant determinants of intention. They rely on the feedback of other stakeholders such as superiors, or more experienced institutional investors before deciding to engage in SRI. They also need organisational factor i.e. caring ethical climate to guide their intention towards SRI. However, no significant relationship is reported for all predictors' relationship with the intentionofbig-sized fund managing group. There is significant relationship between moral intensity and caring ethical climate for large size of fund managed at the behavioural level. It is also explained by studies like Useem et al. (1993), Chiu and Monin (2003), and Solomon and Solomon (2003) where larger size of fund managed increases the level of monitoring behaviour towards investee companies. Larger size of fund indicates more responsibility and more stakeholders at stake; therefore, more socially active responsible investment behaviour is required.

In the context of this study, size of fund managed reflects financial and capital market's reputation among international SRI investors. Large size of fund managed is likely to boost confidence, preference, and interest of the international community to consider emerging markets like Malaysia as an SRI hub. Shortly, management of large funds signifies the talents and ability of local institutional investors in dealing with dynamic SRI. Besides, largesized fund managers tend to discipline errant investee companies. Any withdrawal of money from non-compliant SRI companies may trigger a dropin share price and reduce shareholders' wealth.

\section{CONCLUSION}

\section{Achievement of Objective}

Regarding working experience, it moderates the relationship between attitude and caring ethical climate towards intention among less working experience group of institutional investors. Additionally, working experience moderates the relationship between subjective norms and perceived behavioural control towards intention among more experienced group of institutional investors. Besides, working experience also moderates the relationship between moral intensity and SRI behaviour, in particular among less experienced group of institutional investors. Size of fund managed moderates the relationship between subjective norms and caring ethical climate towards intention among the smaller size of a fund managed group. Also, it also moderated the relationship between moral intensity and caring ethical climate towards SRI behaviour among the larger size of a fund managed.

\section{Implications Of Study}

The first implication highlights the working experience of fund managers. In the Malaysian context, the roles of Talent Corporation (Talent Corp), an agency under the Prime Minister Department can be sought, to attract local talents that are currently serving competitors' market. It is essential to increase the number of highly experienced 
fund managers for the local market; thus, indirectly attracting their professional networks to consider Malaysia as potential regional SRI hub and quantity disclosure among investee companies, and institutional investors.

Competency and skills of local fund managers to deal with complex SRI attributes can be developed through continuous professional development. However, the training and development module should be customisedtofulfil the different needs by considering specific demographic attribute. For example, in preparing training module on the improvement of caring ethical climate, an element of size of fund managed need to be considered, as the moderating effect analysis indicates that caring ethical climate significantly influences intention of smaller size of institutional fund investors. However, the analysis shows that caring ethical climate significantly influences the behaviour of institutional investors managing large-sized funds. Therefore, training module should be designed uniquely to enhance the intentional level of the earlier group, and another training module should be oriented to improve the behavioural level of the latter group.

Relating to caring ethical climate, the outcomes of the study show the presence of implicit organisational factor (Jones, 1991) such as value, moral, norms, interest towards tasks, and loyalty (Frey, 1997). According to Jones (1991), these implicit factors sufficiently predict intention. The lack of explicit organisational factor causes insignificant relationship between caring ethical climate and SRI behaviour. Hence, in the context of emerging market like Malaysia, initiatives need to be intensified to improve the presence of explicit factors. According to Frey (1997), explicit factors include tangible rewards, monetary compensation, promotion, and career advancement. Therefore, strong SRI behaviour can be expected with continuous improvement of explicit factors in institutional investors' entities.

In the context of communicating the perceived magnitude of benefits of SRI, the moderating effect analysis has shown that moral intensity significantly influences the behaviour among less experienced institutional investors. Hence, communication strategies and channels should be designed appropriately by targeting these groups of institutional investors. For instance, non-governmental organisations, media, CSR reporting, and investor relation function should engage frequently less experienced instead of more experienced institutional investors.

In the Malaysian context, multiple efforts should be carried out to enhance the size of local SRI funds. One of the possible efforts is launching more SRI compliant funds; for instance, Permodalan Nasional Berhad (PNB) may launch Amanah Saham Bumiputera 2 (ASB 2) which is fully SRI compliant. PNB also may take the initiative to include SRI consideration in their current funds such as Amanah Saham Wawasan (ASW), Amanah Saham Malaysia (ASM), and Amanah Saham Nasional (ASN). The Employee Provident Fund (EPF) which is considering launchingof EPF 2, may ensure that the future fund is SRI compliant. Besides expanding equity market with SRI funds, policymakers should encourage more SRI bonds in the debt market. The success of Islamic bonds or Sukukshould be replicatedto expand the size of local SRI portfolios and attract global SRI investors into Malaysian financial and capital market.

Furthermore, the analysis has yielded significant moderating effect of working experience and size of fund managed on the link between subjective norms and intention to engage in SRI; in particular for a group of more experienced and small-sized fund managers. It indicated that the perception of others' opinion significantly influenced those groups of institutional investors' motivation towards SRI. Hence, important stakeholders such as regulators, employers, beneficiaries, clients, and co-investors must play a vital role to voice out their preferences and commitments towards SRI in a vocal and constructive manner, as their opinions are important to drive motivation of those groups of institutional investors. These can be carried out by organising more formal and informal engagements with those groups of institutional investors.

\section{Limitations of Study}

SRI consists of three strategies namely screening, shareholders' activism, and community investing (Schueth, 2003; Louche \& Lydenberg, 2006). However, in this study, community investing is omitted from analysis. Hence, it has limited the moderating impact of the size of fundmanaged and working experience towards community investing aspect. The omission is consistent with the argument given by Sparkes (2001). According to Sparkes (2001) community investing is not part of SRI because it involves different actors who are driven by different types of 
motivation and having differing impacts. While referring community investing with the term socially directed investment (SDI), Sparkes (2001, p. 175) further emphasises that "SRI is an equity-based activity, as one of its core aims is to use the power and influence of shareholders to affect corporate behaviour positively. SDI, is essentially a debt-based activity. Second, the essence of SDI is that SDI savers deliberately accept market returns to help others; this is certainly not the intention in SRI".

Besides, in the Malaysian context, community investing is not being carried out by institutional investors, instead, the concept is propagated by other agencies set up by the government, for instance, Amanah Ikhtiar Malaysia (AIM) which provides micro-credit facilities to small entrepreneurs including single mother group (ASriA, 2003). Still, the concept of community investing among companies isto gain momentum, at least through waqf-shares(Shapoee \& Santoso, 2009). Among the pioneers of this concept are Johor Corporation Berhad (Muhamad Don, 2011; Mahmood and Mohd Shafiai, 2013), and recently Bank Muamalat - the second largest Islamic bank in Malaysia that has joined the bandwagon of waqf share. Thus, the omission of community investing has limited our understanding on how institutional investors perceived it as part of SRI strategy.

\section{Recommendation of Future Study}

Future studies may incorporate the examination of behavioural beliefs, normative beliefs, and the control beliefs in SRI behaviour model. In TPB, attitude is influenced by behavioural beliefs, subjective norms are determined by normative beliefs, and perceived behavioural control is predicted by control beliefs (Ajzen, 1991). Previous studies like Randall and Gibson (1991), Kurland (1996), Chang (1998), and Harland, Staats and Wilke (1999) acknowledge the essential of investigating those beliefs in the context of TPB.

Another recommendation relates to organisational ethical climate. Future studies may consider evaluating the potential impact of other types of organisational ethical climate such as instrumental, law \& code, rules, and independence (Victor \& Cullen, 1988; Cullen, Victor \& Bronson, 1993). Emphasis should be given to the impact of instrumental ethical climate, as numbers of previous studies have empirically found that instrumental ethical climate promotes unethical intention and behaviour (see Wimbush, Shepard \& Markham (1997), Flannery \& May (2000), Vardi (2001), Buchan (2005). Through such investigation, a better recommendation can be forwarded to monitor potential organisational climate that could limit the progress of SRI in the local market segment.

\section{ACKNOWLEDGEMENTS}

The paper acknowledges the financial assistance provided by Multimedia University through Special Funding for Social Sciences Research (SFSCR)

\section{AUTHOR BIOGRAPHIES}

Dr. Mohammad Talha is working as Associate Professor in the Department of Accounting and Finance, College of Business Administration, Prince Mohammad Bin Fahd University, Al-Khobar, Saudi Arabia. He teaches Financial Accounting \& Reporting and Managerial Accounting at graduate and MBA level. He has published more than 130 research papers in national and international journals of repute including SCOPUS and ISI. He has also presented papers and attended 43 national and international conferences. Dr. Talha is member of editorial boards of about 27 International Journals on Accounting and Finance. Dr. Talha has also received several awards for excellent teaching and research. E-mail: mtalha@pmu.edu.sa (Corresponding author)

Dr. Abdullah Sallehhuddin is currently the Director of Students Affairs, Multimedia University. He is also the Associate Research Fellow of Accounting Research Institute (ARI) - the Higher Institutions' Centre of Excellence (HICoE) at University Teknologi MARA (UiTM). He did his doctoral thesis in the area of socially responsible investment. E-mail: abdullah.sallehhuddin@mmu.edu.my

Abdul Aziz Abdul Jalil is currently pursuing his doctorate at the Accounting Research Institute of Universiti Teknologi Mara in the area of Forensic Accounting. His research interest includes corporate governance, audit, and ethics in financial and capital market. He is also a Certified Integrity Officer (CIO). E-mail: abd.aziz@mmu.edu.my 
Norzarina Md Yatim is currently pursuing her doctorate at Faculty of Management, Multimedia University in the area of public sector accounting. Her research interest includes financial accounting and reporting among public statutory bodies, accountability, and governance of public statutory bodies. E-mail: norzarina.yatim@mmu.edu.my

\section{REFERENCES}

Abu Samah, B. (2014). Structural equation modeling using AMOS, Serdang: Institute for Social Science Studies, Universiti Putra Malaysia.

Ajzen, I. (1985). From intentions to actions: A theory of planned behavior.in J. Kuhl and J. Beckmann (Eds.), Action-control: From cognition to behavior. Heidelberg: Springer, 11-39.

Ajzen, I. (1991). The theory of planned behavior. Organizational Behavior and Human Decision Processes, 50(2), $179-211$.

Baron, R. M., \& Kenny, D. A. (1986). The moderator-mediator variable distinction in social psychological research: Conceptual, strategic, and statistical considerations. Journal of Personality and Social Psychology, 51(6), 1173-82.

Beal, D., \& Goyen, M. (1998). Putting your money where your mouth is: A profile of ethical investors? Financial Services Review, 7(2), 129-143.

Buchan, H. F. (2005). Ethical decision making in the public accounting profession: An extension of Ajzen's theory of planned behavior, Journal of Business Ethics, 61(2), 165-181.

Chang, M. K. (1998). Predicting Unethical Behavior: A Comparison of the TRA and the Theory of Planned Behavior. Journal of Business Ethics, 17(6), 1825-1834.

Chiu, P., \&Monin, J. (2003). Effective corporate governance: From the perspective of New Zealand fund managers. Corporate Governance, 11(2), 123-131.

Cohn, R. A., Lewellen, W. G., Lease, R. C., \& Schlarbaum, G. G. (1975). Individual investor risk aversion and investment portfolio composition. Journal of Finance,30(2), 605-620.

Cox, P., Brammer, S., \&Millington, A. (2004). An empirical examination of institutional investor preferences for corporate social performance. Journal of Business Ethics, 52(1), 27-43.

Craft, J. L. (2012). A review of the empirical ethical decision-making literature: 2004-2011. Journal of Business Ethics,117(2), 221-259.

Cullen, J. B., Victor, B., \& Bronson, J. W. (1993). The ethical climate questionnaire: An assessment of its development and validity. Psychological Reports, 73(2), 667-674.

Eckel, C. C., \& Grossman, P. J. (1998). Are women less selfish than men? Evidence from dictator experiments. The Economic Journal, 108(448), 726-735.

Flannery, B. L., \& May, D. R. (2000). Environmental ethical decision making in the U.S. metal-finishing industry. Academy of Management Journal, 43(4), 642-662.

Ford, R. C., \& Richardson, W. D. (1994). Ethical decision making: A review of the empirical literature. Journal of Business Ethics, 13(3)205-221.

Frey, B. F. (1997). On the relationship between intrinsic and extrinsic work motivation. International Journal of Industrial Organization, 15(4), 427-439.

Geetha, S.N., \& Vimala, K. (2014). Perception of household individual investors towards selected financial investment avenues. Procedia Economics and Finance, 11(1), 360-374.

Getzner, M., \& Grabner-Krauter, S. (2004). Consumer preferences and marketing strategies for green shares: Specifics of the Austrian market., International Journal of Bank Marketing, 22(4)260-278.

Gregory, A., Matatko, J., \& Luther, R. (1997). Ethical unit trust financial performance: Small company effects and fund size effects. Journal of Business Finance \& Accounting, 24(5)705-725.

Hair, J. F., Black, W. C., Babin, B. J., \& Anderson, R. E. (2010). Multivariate data analysis (7th ed.), New Jersey: Pearson Prentice Hall.

Harland, P., Staats, H., \& Wilke, H. A. M. (1999). Explaining proenvironmental intention and behavior by personal norms and the Theory of Planned Behavior. Journal of Applied Management Accounting Research, 29(12)2505-2528.

Hellsten, S., \&Mallin, C. (2006). Are 'Ethical' or 'Socially Responsible' investments socially responsible? Journal of Business Ethics, 66(4), 393-406.

Islamoglu, M., Apan, M., \& Ayvali, A. (2015). Determination of factors effecting individual investor behaviours: A study on bankers. International Journal of Economics and Financial,5(2), 531-543.

Junkus, J.C., \& Berry, T.C. (2010). The demographic profile of socially responsible investors. Managerial Finance, 36(6), 474481.

Jones, T. M. (1991). Ethical decision making by individuals in organizations: An issues-contingent model. The Academy of Management Review,16(2), 366-395.

$\mathrm{Ku}$ Ismail, K. N. I., \& Chandler, R. (2005). Perceptions of professional investors in Malaysia on the usefulness of quarterly financial reports. Jurnal Pengurusan, 24(1), 105-124.

Kurland, N. B. (1996). Sales agents and clients: Ethics, incentives, and a modified theory of planned behavior. Human Relations, 
49(1), 51-74.

Lehnert, K., Park, Y., \& Singh, N. (2014). Research note and review of the empirical ethical decision-making literature: Boundary conditions and extensions. Journal of Business Ethics, 129(1), 195-219.

Lewellen, W.G., Lease, R.C., \& Schlarbaum, G. G. (1977). Patterns of investment strategy and behavior among individual investors. Journal of Business, 50(3), 296-333.

Lewis, A. (2001). A focus group study of the motivation to invest: 'Ethical/green' and 'ordinary' investors compared. The Journal of Socio-Economics, 30(4), 331-341.

Lodhi, S. (2014). Factors influencing individual investor behaviour: An empirical study of city Karachi. Journal of Business and Management, $16(2), 68-76$.

Loe, T. W., Ferrell, L., \& Mansfield, P. (2000). A review of empirical studies assessing ethical decision making in business. Journal of Business Ethics, 25(3), 185-204.

Louche, C., \& Lydenberg, S. (2006). SRI: Differences between Europe and United States.Working paper No. 22. Belgium: Ghent University, 1-37.

Mahmood, N. A., \&Mohd Shafiai, M. H. (2013). Potensi wakaf korporat kepada pemilikan ekuiti Muslim: Kajian di Wakaf AnNur Corporation. Prosiding PERKEM,8(1), 383-396.

Martin, R., \&Nisar, T. M. (2007). Activist investment: Institutional investor monitoring of portfolio companies. Management Decision, 45(5), 827-840.

McLachlan, J., \& Gardner, J. (2004). A comparison of socially responsible and conventional investors. Journal of Business Ethics, 52(1), 11-25.

Menkhoff, L., Schmeling, M., \& Schmidt, U. (2013). Over confidence, experience and professionalism: An experimental study. Journal of Economic Behavior and Organization, 86(3), 92-101.

Mishra, K.C. \& Metilda, M.J. (2015). A study on the impact of investment experience, gender, and level of education on overconfidence and self-attribution bias. IIBM Management Review, 27(4), 228-239.

Muhamad Don, M. A. (2011). Wakaf korporatoleh Johor Corporation Berhad: Amalanda Beberapa Isu Pelaksanaan. Academic Journal UITM Johor, 10(1), 229-241.

Nilsson, J. (2008). Investment with a conscience: Examining the impact of pro-social attitude and perceived financial performance on SRI behavior. Journal of Business Ethics, 83(2), 307-325.

Nilsson, J. (2009). Segmenting socially responsible mutual fund investors: The influence of financial return and social responsibility. International Journal of Bank Marketing, 27(1), 5-31.

O'Fallon, M. J., \& Butterfield, K. D. (2005). A review of the empirical ethical decision-making literature: 1996-2003. Journal of Business Ethics, 59(4), 375-413.

Owen, A. L., \& Qian, Y. (2008). Determinants of SRI decisions. Working paper, Hamilton College, New York: Hamilton College, 1-10.

Perez-Gladish, B., Benson, K., \& Faff, R. (2012). Profiling socially responsible investors: Australian evidence. Australian Journal of Management, 37(2), 189-209.

PricewaterhouseCoopers. (2002). Market readiness for disclosure-based regulation: Highlights from the survey on the readiness of the Malaysian capital market participants for DBR. Kuala Lumpur: PwC

Randall, D. M., \& Gibson, A. M. (1991). Ethical decision making in the medical profession: An application of the theory of planned behavior. Journal of Business Ethics,10(2), 111-122.

Riley, W. B., \& Chow, K. V. (1992). Asset allocation and individual risk aversion. Financial Analysts Journal, $48(6), 32-37$.

Rosen, B. N., Sandler, D. M., \&Shani, D. (1991). Social issues and SRI behavior: A preliminary empirical investigation. The Journal of Consumer Affairs, 25(2)221-234.

Sadiq, M.N., \&Ishaq, H.M. (2014). The effect of demographic factors on behavior of investors during the choice of investment: Evidence from twin cities of Pakistan. Global Journal of Management and Business Research, 14(3)46-56.

Schueth, S. (2003). Socially responsible investing in the United State. Journal of Business Ethics43(3), 189-194.

Sethi, S. P. (2005). Investing in socially responsible companies is a must for public pension funds - because there is no better alternative. Journal of Business Ethics, 56(2), 99-129.

Shapoee, R., \&Santoso, B. (2009). Wakaf korporat: Satu pendekatan kepada tanggung jawab sosial korporat pada perspektif syiar ekonomi (satukajian di Johor Corporation, Malaysia). Surabaya: International Conference on Corporate Law (ICCL), June 1-3,1-23.

Shievanen, R., Rita, H., Scholtens, B. (2013). The drivers of responsible investment: The case of European pension funds. Journal of Business Ethics, 117(1), 137-151.

Solomon, A., \& Solomon, J. F. (2003). The SRI dilemma for pension fund trustees: Some perceptions of their evolving role. Working paper, No. 7, Cardiff: Business Relationships, Accountability, Sustainability and Society (BRASS), 1-45.

Sparkes, R. (2001). Ethical investment: Whose ethics, which investment? Business Ethics: A European Review, 10(3)94-205.

Tan, Y. W. G., \& Komaran, R. J. (2006). Perceptions of CSR: An empirical study in Singapore. In Strategic Management Policy in the 13th Annual International Conference on Advances in Management. Singapore: Research Collection Lee Kong Chian School of Business, 1-14.

Tippet, J., \& Leung, P. (2001). Defining ethical investment and its demography in Australia. Australian Accounting Review, 11(3), 44-55. 
Useem, M., Bowman, E., Myatt, J., \& Irvine, C. (1993).US institutional investors look at corporate governance in the 1990s. European Management Journal, 11(2), 175-189.

Vardi, Y. (2001). The effects of organizational and ethical climates on misconduct at work. Journal of Business Ethics, 29(4), 325-337.

Victor, B., \& Cullen, J.B. (1987). A theory and measure of ethical climate in organization. In W. C. Frederick (Ed.).Research in Corporate Social Performance and Policy. Connecticut: JAI Press, 51-71.

Victor, B., \& Cullen, J.B. (1988). The organizational bases of ethical work climates. Administrative Science Quarterly, 33(1), $101-125$.

Warren, W. E., Stevens, R. E., \& McConkey, C. W. (1990). Using demographic and lifestyle analysis to segment individual investors. Financial Analysts Journal,46(2), 74-77.

Wimbush, J. C., Shepard, J. M., \& Markham, S. E. (1997). An empirical examination of the relationship between ethical climate and ethical behavior from multiple levels of analysis. Journal of Business Ethics, 16(16), 1705-1716.

Woodward, T. (2000). The profile of individual ethical investors and their choice of investment criteria, Poole, Bournemouth: Bournemouth University Press. 